\title{
SLC7A8 Gene
}

National Cancer Institute

\section{Source}

National Cancer Institute. SLC7A8 Gene. NCI Thesaurus. Code C119001.

This gene plays a role in the transport of small and large neutral amino acids. 